Ethiopian Journal of Environmental Studies \& Management 8(4): 433 - 441, 2015.

ISSN:1998-0507

doi: http://dx.doi.org/10.4314/ejesm.v8i4.8

Submitted: February 27, 2015

Accepted: May 04, 2015

\title{
THE IMPACTS OF LAND USE CHANGES ON LIVELIHOOD OF THE MAASAI COMMUNITY IN KAJIADO COUNTY, KENYA
}

\author{
${ }^{*}$ KOMBO, N.P. ${ }^{1}$ AND EKISA, G.T. ${ }^{2}$ \\ ${ }^{1}$ Hifadhi Consultancy, P.O. BOX 192-50405 Butula, Kenya \\ ${ }^{2}$ University of Eldoret, School of Environmental Studies, Department of Applied \\ Environmental Social Sciences (Human Ecology Division) P. O.Box 1125-30100 Eldoret, \\ Kenya
}

\begin{abstract}
This paper assesses impacts of land use changes on livelihoods and subsequent environmental degradation in Amboseli ecosystem of Southern Kenya. The paper employed field surveys using questionnaires, interview and focus group discussion to collect data. Findings revealed that slight majority (56\%) of residents depend on agriculture or pastoralism as their main source of livelihood, reflecting their dependence on the land and resources. It was found that practices such as deforestation and use of fertilizers are increasing the environmental degradation and further perpetuating challenges related to environmental conservation that greatly affect their livelihoods. Therefore, these practices are not sustainable and changes must be made to new sustainable and dependable livelihood strategies. Strategies such as land use planning; planting of trees, agro-forestry, and community education on conservation practices should be implemented to improve livelihoods. Although policy and enforcement play important role in environmental conservation, it is equally important that sustainable strategies are generated and implemented on a local level to alleviate effects of land use changes and work towards reduction of environmental degradation.
\end{abstract}

Key Words: Land utilization, Livelihoods, Sustainable development, Degradation

\section{Introduction}

Changes in land use are to a large extent a reflection of how society responds to socio-economic, institutional and management practices (Adeniyi, 1980). The United Nation Economic Commission of Europe [UNECE] (2004) defines land use as the manner in which land is used, including the nature of the vegetation upon it surface. In the Amboseli ecosystem, many pastoralists are switching over to agricultural practices in order to adapt to the lack of available resources. Many families have decreased the number of livestock they own and, in order to generate a sufficient amount of income, turned to cultivating some land for crops (Campbell et al., 2000). The profitability of agriculture in combination with a fear of losing land rights has also fuelled the desire of many Maasai to subdivide their communally owned pastoral lands and convert their plots for crop cultivation or sell their land to other agricultural groups immigrating to

*Corresponding Author: Kombo, N.P.

Email: okinjapaul2011@gmail.com 
the area. However, agriculturalists also face challenges related to climate change, as rainfall is the single most important factor influencing crop production (Rutten, 1999). As a source of livelihood, rain-fed agriculture is highly vulnerable to drought and rainfall variability and it is increasingly important to study the losses of livelihood resulting from environmental scarcities of land and water (Ohlsson, 2000).

Livelihood options denote a wide range and combination of activities and choices that people undertake in order to achieve their livelihood goals. They include productive activities, investment strategies and productive choices. These strategies are composed of activities that generate means of survival. The categories and sub categories are potential components of livelihood strategies. Further, they are a dynamic process. People combine activities to meet their various needs at different levels and on different geographical or economic levels.

Arid and semi-arid parts of Kenya are traditionally home to pastoralists, though agriculture is increasingly practiced in suitable areas adjacent to wetlands and water sources. In recent years, dramatic changes in climate have resulted in many people to change their livelihood strategies and land use practices in order to adapt to changes in their environment. Maasai Community are particularly vulnerable to the effects of droughts, as they are more likely to live in arid and semi-arid lands and are highly dependent on both water and forage for their livestock. To these pastoralists, livestock are not just a source of protein, but are representative of income, savings, social status, and security. During droughts, the demand for livestock products, such as milk and meat, are significantly lower than that of grains. This lack of demand is accompanied with a decrease in productivity, and pastoralists are often forced to sell their cattle instead of letting them starve to death (Orindi et al., 2007). The need of water access and forage for livestock has also resulted in increased conflicts between pastoralists and sedentary farmers. Together, these factors make it difficult to sustain a pastoralist lifestyle, resulting in many pastoralists switching to agricultural practices (Campbell et al., 2000).

Assessing the impact of land use changes on livelihood strategies is important for understanding what factors influence the way that land is used and how natural resources are conserved within the community. In investigating the effects of land use changes on livelihoods, it is important to recognize the ways in which these changes impact differently on environment sustainability. Environmental changes resulting in new economic pursuits and livelihood strategies are not always beneficial to everyone and can result in the further marginalization of groups lacking homeland resources, education, or specialized skill sets necessary for participating in the newly 'developed' economy (Chhetri, 2006). According to Chambers and Conway (1991), a livelihood is considered sustainable when it "can cope with and recover from stress and shocks," without compromising the livelihood of future generations.

It is increasingly necessary to examine interactions between people and the environment and the implications these have on livelihoods and environmental sustainability. Emphasis must be placed on collective activities in order for the goal of sustainable development to be actualized (Akinwale, 2010). Therefore, this paper examines the impacts of land use changes on livelihoods of the Maasai Community and subsequent consequences on the environmentally sustainability. The paper specifically identifies major land use and 
livelihood strategies in the Maasai community; and establishes the effects of land use changes on the environment in the Maasai Community.

\section{The Study Area}

The Loitokitok Sub-County of southern Kenya lies in the foothills of Mt. Kilimanjaro and area is classified as one of the 21 Arid and Semi-Arid Land (ASAL) Counties in Kenya and consists of small areas with water availability adjacent to vast, dry grasslands. The geographic coordinates of the study area from Kimana are 0337489-9690585; 0325770-9680321; 0337183-9719620; and 043915397022943. The region receives an annual rainfall of about $700-850 \mathrm{~mm}$ and the landscape is comprised of plains and occasional hills and valleys (NEMA, 20092013). The hydrology of the region is heavily influenced by Mt. Kilimanjaro in terms of both rainfall received and presence of ground water. The soils in the area, which were mostly formed from volcanic ash, are well drained, porous, and have high organic matter content, making them particularly good for agricultural practices (McDaniel, 2012; NEMA, 2009-2013).

Bush lands and open grasslands (Acacia Commiphora mosaic) are the dominant vegetation of the area, with some swamps lying at the base of Kilimanjaro. However, the vegetation composition has changed significantly in the past decade with most woodland areas being converted into marginal crop farming areas, swamps into irrigated land, and grasslands to bush lands due to overgrazing (Ntiati, 2002). The area is considered an "environmental hotspot," due to these evident and dramatic changes caused by human activity on the landscape in recent years (UNEP, 2009).

Prior to colonization, the land was dominated by the Maasai tribe for herding of cattle, goats, and sheep. However, colonial land demarcation and the establishment of national parks and reserves in the 1930s encouraged the expansion of agricultural practices in the region, resulting in competition between herding, cultivation, and tourism (Campbell et al., 2000). In an effort to mitigate conflict between these groups and encourage fair allocation of natural resources, six group ranches were under the Land (Group Representative) Act of 1968 (Ntiati, 2002). These group ranches were formed with the objective of increasing environmental conservation within the ecosystem through improving livestock productivity and reducing overgrazing and other unsustainable land use practices (Nyariki et al., 2009). 


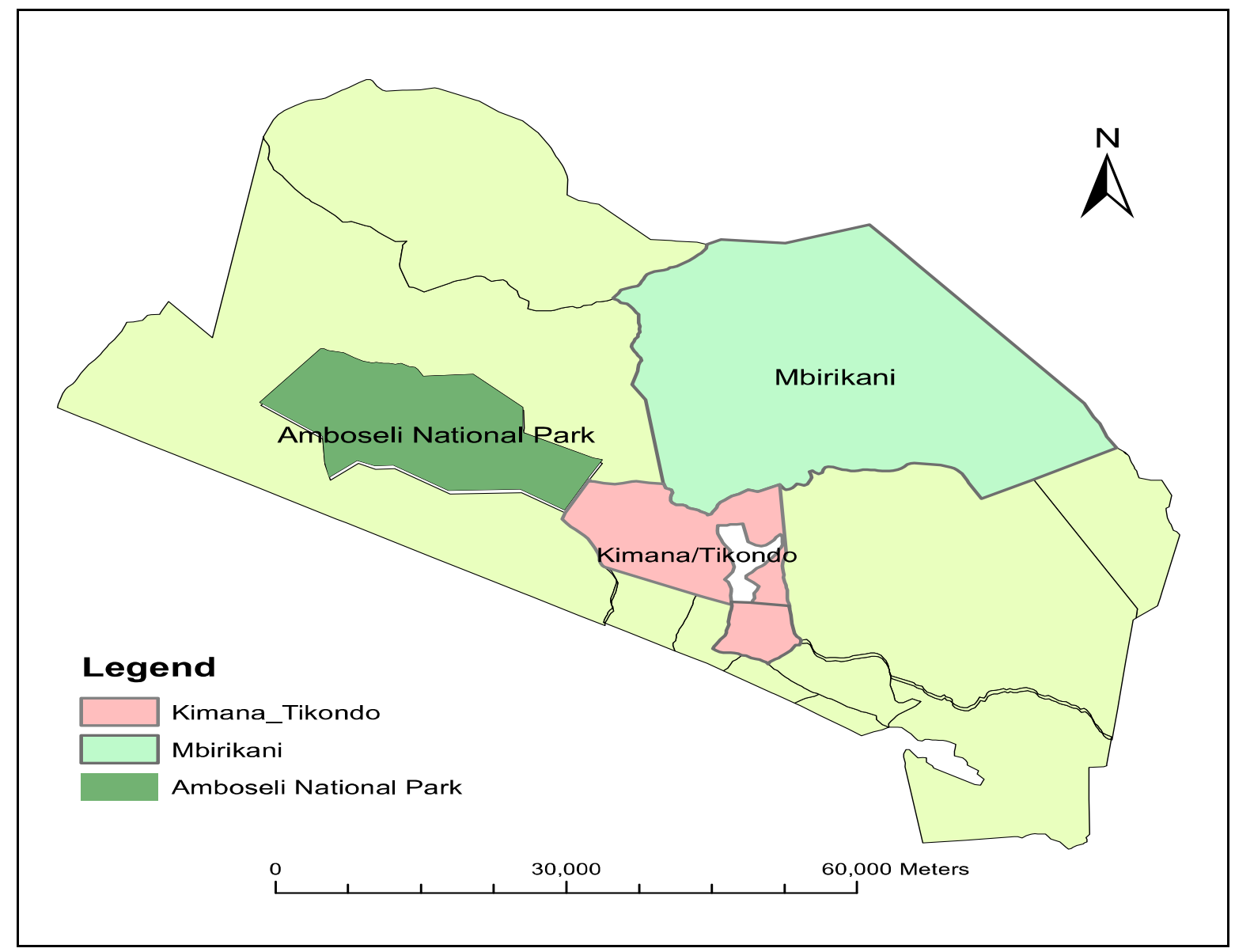

Figure 1: Map of Loitokitok sub-county showing the study area

\section{Methods}

\section{Samples Collection}

Total samples of 162 households were randomly selected for questionnaire interviews in the Loitokitok Sub-County of Kajiado County, Kenya. Further interviews were done with the Ministry of Agriculture and Rural Development personnel. Group discussions with the local leaders through PRAs were also undertaken. To ensure success of the interviews, enumerators were recruited from the local administrative sublocations to avoid the language barrier and also ensure co-operation. The clusters visited for questionnaire interviews were Mbirikani; Kimana-Tikondo; and Amboseli national park as shown in figure 1 . Homesteads (manyattas) were visited both in the morning and evenings. At the PRA meetings the Maasai elders, in addition to participating in identifying land use changes in their location, were asked about the impacts related to land use changes on livelihood and environmental degradation in the Maasai community.

The Loitokitok Sub-County of southern Kenya lies in the foothills of Mt. Kilimanjaro and area is classified as one of the 21 arid and semi-arid (ASAL) districts in Kenya and consists of small areas with water availability adjacent to vast, and dry grasslands; was clustered based on administrative boundaries, and used for selection of households which were included in the survey, with a random sample of households chosen from areas of different clusters. Descriptive data analyses were employed especially chi-square to analyze collected data from the field to 
establish the correlation between the variables.

\section{Results}

\section{Land Use and Livelihood Strategies}

Majority of the residents interviewed used their land for agriculture (62.3\%). The next most common land use was pastoralism $(35.2 \%)$, followed by agropastoralism $(2.5 \%)$ as shown in table 1 . The main source of income of the respondents was primarily agriculture, representing $55.6 \%$ of those interviewed. Pastoralism was the second most common source of income $(26.7 \%)$, followed by agropastoralism $(11.7 \%)$, business $(4.9 \%)$, and other employment $(1.3 \%)$ as indicated in table 2. When the two most common income sources, agriculture and pastoralism, were compared, the data reflected that annual income was, on average, higher for pastoralists than agriculturalists. A higher percentage of pastoralists reported annual incomes in the higher income brackets than agriculturalists.

Table 1: Land uses in Maasai Community

\begin{tabular}{lcc}
\hline Land use & Frequency & Percent \\
\hline Agro-pastoralism & 4 & 2.5 \\
Pastoralism & 57 & 35.2 \\
Agriculture & 101 & 62.3 \\
\hline Total & 162 & 100.0 \\
\hline
\end{tabular}

Table 2: The main income source

\begin{tabular}{lcc}
\hline Main income source & Frequency & Percent \\
\hline Agriculture & 90 & 55.6 \\
Other employment & 2 & 1.3 \\
Business & 8 & 4.9 \\
Agro-pastoralism & 19 & 11.7 \\
Pastoralism & 43 & 26.5 \\
\hline Total & 162 & 100.0 \\
\hline
\end{tabular}

Respondents spent their income on a variety of things, with the most common one being food (88\%). After food, $77 \%$ of those interviewed reported spending their income on education, $66 \%$ on clothes, $32 \%$ on medical, $28 \%$ on agriculture, and $22 \%$ on livestock. Food supply of the respondents was compared with land use types, reflecting similar results between each land use type. Majority of the respondents $(73 \%)$ reported having a sufficient food supply. No correlation was found between land use type and food supply $\left(\chi^{2}=0.063, \mathrm{df}=2, \mathrm{p}=0.969\right)$.

Of the agriculturalists interviewed, majority $(63 \%)$ reported using $25-50 \%$ of their harvest for subsistence. $17 \%$ reported using less than a quarter of their total harvest, while $16 \%$ used $51-75 \%$ of their harvest and 4\% used over $76 \%$ for subsistence.

\section{Effects of Land Use on Environment}

Respondents reported on trends in grass cover and tree cover in their area in recent years. Half $(50 \%)$ of the respondents reported an increase in grass cover in the area, $25 \%$ reported decreasing grass cover, and $21 \%$ saw no visible change. The remaining $4 \%$ of respondents were unsure or had not lived in the area long enough to report any trends. Slightly over half $(51 \%)$ of the respondents reported seeing a decrease in tree cover in recent years, while $32 \%$ reported increasing tree cover, and 
$14 \%$ saw no change. The remaining 3\% were unsure or had not lived in the area long enough to report any trends. Respondents reported a mix of responses relating to changes in soil erosion in recent years, with $38 \%$ reporting no change, $36 \%$ reporting an increase in erosion, and 24\% reporting a decrease in erosion. The remaining $2 \%$ of respondents were unsure or had not lived in the area long enough to report any trends as shown in table 2 .

Table 3: Trends of land use effects on environment

\begin{tabular}{lcccccc}
\hline Trends & \multicolumn{2}{c}{ Tree cover } & \multicolumn{2}{c}{ Grass cover } & \multicolumn{2}{c}{ Soil erosion } \\
\cline { 2 - 7 } & Frequency & $\%$ & Frequency & $\%$ & Frequency & $\%$ \\
increasing & 52 & 32.0 & 81 & 50.0 & 58 & 36.0 \\
decreasing & 83 & 51.0 & 41 & 25.0 & 38 & 24.0 \\
no change & 23 & 14.0 & 34 & 21.0 & 62 & 38.0 \\
unsure & 4 & 3.0 & 6 & 4.0 & 4 & 2.0 \\
\hline Total & 162 & 100.0 & 162 & 100.0 & 162 & 100.0 \\
\hline
\end{tabular}

Pastoralists reported on trends in the amount of available pasture in recent years. Of the pastoralists interviewed, $62 \%$ saw a decrease in pasture in their area, $20 \%$ saw an increase, and $18 \%$ reported no change. Agriculturalists were asked about chemical use in cultivation of crops. Majority of the respondents use fertilizers $(86 \%)$ and pesticides $(92 \%)$ on their crops. Very few agriculturalists reported using herbicides $(17 \%)$, and the remaining $83 \%$ did not. Once more they were asked a series of questions regarding their previous knowledge of soil conservation methods. Over half $(59 \%)$ reported having some knowledge of conservation techniques, with the remaining $41 \%$ having no previous knowledge.

Level of education was compared with knowledge of soil conservation methods. A correlation was found between the education level of the respondent and their knowledge on soil conservation $\left(\chi^{2}=15.767, \mathrm{df}=3, \mathrm{p}=0.001\right)$. Respondents with a higher level of education were more likely to have some knowledge of soil conservation methods than those with no education. Respondents reported using a variety of soil conservation methods, including tilling, constructing furrows, crop rotation, planting trees, constructing terraces, and using manure. The most common methods implemented by respondents was furrows $(45 \%)$, followed by construction of terraces $(29 \%)$, planting trees $(19 \%)$, using manure $(9 \%)$, tilling $(8 \%)$, and crop rotation $(5 \%)$.

\section{Discussion \\ Land Use}

Agriculture was reported as the primary land use throughout the study area, reflecting a change from the pastoral practices of the Maasai people who historically dominated the region. Of the respondents interviewed, $62.3 \%$ used their land for agricultural purposes. This change is likely a result of two factors: a decline in pastoral resources and the rising profitability of agriculture. Recent increase in drought occurrence and intensity has led to a decline in water and forage resources, putting a stress on the livelihoods of pastoralists. Changes in land tenure policies favoring land privatization has led to communal land fragmentation and sale, facilitating more agricultural practices (Orindi et al., 2007). The recent trend toward sedentarization has also contributed to increased crop cultivation among the traditionally nomadic Maasai (Mung'ong'o and Mwamfupe, 2003). 
These changes, however, hold consequences for the livelihoods of the remaining pastoralists and further contribute to environmental degradation. As cultivated land increases in the more fertile areas of the district, pastoralists are pushed into the drier, more arid areas, putting more stress on the land and resulting in decreased resource availability for the livestock and people (UNEP, 2009). Agricultural practices also have many negative impacts on the environment, contributing to deforestation, increased soil erosion, and decreased soil moisture and water availability (Maitima et. al., 2009). These findings reflect the importance of more land use planning and policy to insure that land use is sustainable and dependable for the livelihoods of the people.

\section{Livelihoods and Income}

The respondents had a variety of income sources, including agriculture, employment, business, agro-pastoralism, and pastoralism. Of these income sources, the two most common were agriculture and pastoralism, as expected. When of these two livelihood practices was compared, it was found that pastoralists, on average, had a higher annual income. However, these results are not very accurate, as many pastoralists reported the profit they would make if they sold all of their livestock in one year rather than the income they actually make from the intermittent sale and keeping of livestock throughout the year. There was also a much smaller respondent pool for pastoralists than agriculturalists, skewing the data. Regardless, the fact that majority of the respondents depend on either agriculture or pastoralism as their main source of income is significant in showing the dependence these people have on the environment and natural resources. This dependence is direct and makes them particularly vulnerable to climate change and the subsequent loss of resources (NEMA 20092013).

Incomes were spent on various uses, including clothes, agriculture, medical, livestock, food, and education. Buying food was the most common use of income among the respondents. This reflects the extent to which food security is linked to income source. It is therefore crucial that livelihood practices are sustainable and bring in a stable income. Variables that may affect this stability, such as climate change, must be identified and addressed in order to increase livelihood and food security.

Data showed that slightly less than $3 / 4$ of respondents had a sufficient food supply each day, independent of their land use practices. This reflects the vulnerability of these livelihood strategies and the effects that climate change has already had on diminishment of resources that are vital to the success of agricultural and pastoral practices. It is clear that these practices are growing increasingly less dependable and unstable, as they can no longer provide sufficient food supply and income.

Of the agriculturalists interviewed majority used most of their harvest for subsistence purposes. This further emphasizes the importance of a good and stable harvest on livelihoods. People are incredibly dependent on their harvest as a source of food, meaning that bad harvests due to climate change and drought have significant impacts on both food security and ability to bring surplus food to the market. This dependency emphasizes the importance of finding sustainable agricultural solutions in the face of climate change. Beyond personal food security, decreased harvest has substantial impact on the country as a whole, as it largely contributes to the nation's economy (UNEP, 2009). 


\section{Conclusion}

Land use in the Amboseli ecosystem is primarily for agriculture and pastoralism and human activity on the land is causing increased stress, loss of resources, and overall environmental degradation. Trends such as loss of tree cover and decrease in pasture reflect the impacts that the people are having on the land. Overgrazing has led to a visible decrease in pasture and farming practices such as the use of fertilizers and pesticides are causing pollution and degradation of land and water. In an effort to deal with the effects of changing land use, livelihood strategies are in fact perpetuating the problem through further land degradation, depletion of resources, and general unsustainable practices. This vicious cycle must be stopped through the implementation of sustainable development strategies in order to reverse environmental degradation, increase livelihoods, and ultimately alleviate poverty. Solutions must be backed by solid policy framework but invented and implemented on the local level with the input of the community. It is important to take into account the livelihoods of the local people when constructing environmental and conservation programs, and to find strategies that address their problems directly at both the household and community level.

\section{Recommendations}

This paper recommends the following: Increase tree planting within the group ranches to provide better catchment of groundwater and improve water resources during droughts.

Educate and facilitate the implementation of more sustainable cultivation practices meant to prevent erosion and increase soil productivity. Such practices include: mixed farming, crop rotation, resting soil between planting seasons, planting cover crops, and using natural fertilizers like manure and compost.

\section{Acknowledgement}

We would like to thank the research assistants for their tiresome efforts in collecting and analyzing the data. We would also like to thank the drivers and guides who helped us throughout our fieldwork. Lastly, huge thanks to the entire community for working with us, taking the time to answer our questions and tell us about their lives.

\section{References}

Adeniyi, P.O. (1980). Land use change Analysis using sequential Aerial Photograph and Computer techniques. Photogrammetric Engineering and Remote Sensing, 46 (11): 1447-1464.

Akinwale, A.A. (2012). Livelihoods and environmental challenges in coastal communities of Nigeria. African Journal of Food, Agriculture, Nutrition and Development, 11(7): 5661-5673.

Campbell, D.J., Gichohi, H., Mwangi, H. A. and Chege, L. (2000). Land use conflict in Kajido District, Kenya. Land Use Policy, 17:337-34

Chambers, R. and Conway, G. R. (1991). Sustainable rural livelihoods: Practical concepts for the 21st Century. IDS Discussion Paper, No 296. Retrieved August 23, 2014, from https://www.ids.ac.uk/vfiles/Dp296.p df

Chhetri, R.B. (2006). Changing environments and livelihoods in Nepal: an overview. Contributions to Nepalese Studies, 33: 1-14.

Maitima, J.M., Mugatha, S.M., Reid, R.S., Gachimbi, L.N., Majule, A., Lyaruu, H., Pomery, S., Mathai, S. and Mugisha, D. (2009). The linkages 
between land use change, land degradation and biodiversity across East Africa. Afr. J. of Env. Sci. and Tech. 3:310-325.

McDaniel, P. (2012). University of Idaho, College of Agricultural and Life Sciences.

http://www.cals.uidaho.edu/soilorders /index.htm (accessed on 22 November 2012).

Mung'ong'o, C.G. and D.G. Mwamfupe. (2003). Poverty and changing livelihoods of migrant Maasai pastoralists in Morogoro and Kilosa districts, Tanzania. Research Report, No. 03.5.

NEMA. (2009). Kajiado District Environment Action Plan.

Ntiati, P. (2002). Group Ranches Subdivision Study in Loitokitok Division of Kajiado District, Kenya.LUCID Project, International Livestock Institute, Nairobi, Kenya.

Nyariki, D.M., Mwang'ombe, A.W and Thompson, D.M. (2009). Land-use change and livestock production challenges in an integrated system: the Masai- Mara ecosystem, Kenya. Human Ecology Journal, 26(3): 163173.

Ohlsson, L. (2000). Livelihood Conflicts: Linking poverty and environment as causes of conflict. Swedish International Development Cooperation Agency (Sida)

Orindi, V.A., Nyong, A. and Herrero, M. (2007). Pastoral livelihood adaptation to drought and institutional interventions in Kenya. Human Development Report Office, Occasional Paper, 54.

Rutten, M. (1999). Explanatory frameworks for non-sustainable natural resource management practices: a critique of the perception rationale. 237-258 pp.

UNEP. (2009). Kenya: atlas of our changing environment. Nairobi, Kenya 